\title{
Research on Optimization Strategy of the Salary Management of Small and Medium-Sized Enterprises in China under the Knowledge Economy
}

\author{
Chao ZENG \\ Jiangxi Normal University Science and Technology College \\ Nanchang, China
}

\author{
Wen-fang FANG \\ Jiangxi Normal University Business School \\ Nanchang, China
}

\begin{abstract}
The small and medium-sized enterprise has become to promote China's economic and social development of a force with reckoned. Although the small and medium-sized in our country enterprise development by leaps and bounds, but its in human resources management, especially the compensation management still exist many problems, which are become a bottleneck of the development of small and medium-sized enterprises in our country. In this paper, the reason of small and medium-sized enterprise salary management in our country was studied. Additionally, we analyzed the main problems of small and medium-sized enterprise salary management, and puts forward relevant countermeasures.
\end{abstract}

Keywords-small and medium-sized enterprises; salary management; restriction factor; optimization

\section{INTRODUCTION}

Human resource has become the first resources of enterprises in the era of knowledge economy. Human resources as a source of competitive advantage in a growing number of small and medium-sized enterprises. The compensation management is an important content of human resource management. Through the salary management, it will help to improve staff enthusiasm, work efficiency and work effect, bring profits for the enterprise [1]. The small and medium-sized enterprise can establish perfect compensation management mechanism, will directly affect the survival and development of enterprise.

\section{THE REASON OF ENHANCE THE SALARY MANAGEMENT OF SMALL AND MEDIUM-SIZED ENTERPRISES UNDER THE KNOWLEDGE ECONOMY IN OUR COUNTRY}

Compensation management is dynamic management that the enterprise to staff salaries, salary payment, salary allocation. Salary management for enterprise development has the very vital significance.

\section{A. Improve efficiency and profitability}

Salary is connected to the enterprise and employees. Under the enterprise faces the enormous pressure of market competition, salary lever principle can make the enterprise in the competition. Scientific and reasonable salary directly decides the labor efficiency. Pay itself does not directly bring the enterprise performance and profitability, but can through effective compensation management and practice, make employee with labor and production data can create the wealth of the enterprise. Therefore, the salary management has more advantages to enhance enterprise efficiency and profitability.

\section{B. Improve staff enthusiasm and labor efficiency}

The salary management of small and medium-sized enterprise is a kind of dynamic management of people, the essence of which is to be managers to do managers want to do. This needs to establish a mechanism to be the manager's behavior in line with the requirements of managers, and management will be successful. The process of salary management to enhance the employee incentive. It can greatly stimulate staff's work enthusiasm, and improve labor efficiency. Therefore, the salary management is not only related to life support, social relations and demand respect. In some ways, it can meet the needs of self value realization.

\section{Promote rational allocation and use of human resources}

Salary as the basic means to realize rational allocation of human resources, it plays a very important role in the human resources development and management. It represents the characteristics of small and medium-sized enterprises demand for human resources aspect, also reflects the labor suppliers provide different labor ability and the basic characteristics of quality. Market-oriented salary management mechanism is essentially a mechanism of efficiency. It is primarily through the flow of labor and market competition, in the balance of supply and demand of salary and the salary difference to guide human resource configuration. This mechanism can timely, accurately reflect the scarcity of all kinds of labor. And workers through flow or post to maximize salary also find the position of doing everything they can and to make a human resource allocation and use more reasonable.

\section{Promote social stability and development}

The consumer salary not only guarantee the living need of the laborers, and realize the reproduction of labor workers. In the sense of compensation management, if the small and medium-sized enterprises have low salary standard for labor, workers' basic life will be affected, and labor costs cannot be fully compensated. But, if the small and medium-sized enterprises have high salary standard for labor, it will pose great influence to the product cost, lead to the enterprise cost burdens. 
Therefore, the small and medium-sized enterprises as an important part of the national economy, if more complete salary management system will alleviate the social pressure and they can provide important guarantee for the stable development of society.

\section{THE CONSTRAINT OF THE SALARY MANAGEMENT OPTIMIZATION OF SMALL AND MEDIUM-SIZED ENTERPRISES \\ UNDER THE KNOWLEDGE ECONOMY IN OUR COUNTRY}

At present, the small and medium-sized enterprise salary management in our country facing the more and more challenges of fierce, at the same time, the main problems existing in the compensation management is increasingly highlighted, and it mainly manifested in the following aspects.

\section{A. The unreasonable of salary strategy planning}

At present, the small and medium-sized enterprises in our country are faced with such a common situation, that is, salary strategy does not match enterprise overall strategy and human resource strategy. Mainly reflects in the following respects: one is the lack of overall strategic considerations on salary strategy planning, and it didn't set out from the global; the other is the salary just as a kind of nature into spending on employees' labor. It just a means of attracting employees, and ignore the salary incentive for employees and support for corporate strategy [2].

\section{B. The behind mode of salary management}

At present, there are three kinds of mainstream salary management model in our country. One is the high incentive mode. This mode has the advantage of incentive strength and high elasticity, but also the most advanced and effective salary management model. Second is the highly stable mode. The salary management mode is characterized by low staff turnover but poor incentive, artificial cost burden. It is the least used relatively backward mode. Third is the combination of moderate incentive and stable mode. This salary management mode has the advantage that meets the requirements of the safety of the employees, reduce staff turnover rate and improve the enterprise incentive. The model in three kinds of salary management model is relatively advanced mode. In our country, nearly half of the small and medium-sized enterprises to select the high stability salary management mode. Less than a third of small and medium-sized enterprises to choose the moderate combination of incentives and stable modes. So small and medium-sized enterprise salary management model as a whole is still relatively backward.

\section{The unvalued of internal salary}

The enterprise often only pay attention to employee external salary in salary management, namely, the usual basic salary, benefits, bonuses and other material salary. But the enterprise ignored the internal salary, which has a great incentive to employee staff. Internal salary refers to the staff because of its excellent work and the spirit of rewards, such as praise and promotion. The internal salary can give employees a sense of self-esteem, and increase the staff's sense of pride. Some enterprises have low attention for the internal salary of employees, and even some enterprises in staff the spirit of care is almost zero, it also makes the enterprise cultural atmosphere is very cold.

\section{The unfair level of salary}

The salary management usually adopts simple standard wage system for most of small and medium-sized enterprises in our country. The level is less for wage, and the different technical requirements of worker have little difference with salary levels. Management and production personnel salary level have slight difference with salary levels. The average tendency is more obvious. It seems fair, in fact, is not fair. In addition, the salary issue of the small and medium-sized enterprises in our country existence very big subjectivity and arbitrariness. Surface salary absolute quantity increased, but did not consider the influence of the factors related to changes in prices change, cause the relative abundance of pay have not been in the true sense of growth.

\section{E. The imperfect of welfare security system}

In terms of welfare, most companies tend to just take it as a kind of hygiene factors, and did not high degree of attention. According to the survey found that the welfare of the small and medium-sized enterprises is the single, mainly embodied in the following respects. Firstly, most companies only offer legal benefits, and does not provide non-statutory benefits. Secondly, among statutory welfare programs, most enterprises only provide endowment insurance and medical insurance. For unemployment, work injury and maternity insurance provider enterprise proportion is very small in the small and mediumsized enterprises [3]. Thirdly, in non-statutory benefits program, also limited to provide transportation, meal allowance, the welfare of the sick leave, etc. For other aspects, like providing recreational facilities, the psychological consultation and service training there is almost no chance in the small and medium-sized enterprises.

\section{F. The scientific of performance assessment}

The content of the assessment of constraint mechanism including performance plans, performance implementation, performance feedback and performance improvement. The enterprise, however, can do little, is rare in the small and medium-sized enterprises. From planning to implementation, from the feedback to plan improvements, assessment restraint mechanism is a set of linked processes, lack of any link that enterprise assessment constraint mechanism is not perfect. However, the small and medium-sized enterprise assess constraint mechanism to implement usually attention to link only one or two aspects.

\section{G. Unscientific salary system}

The salary system is the fundamental law of enterprise compensation, and the foundation and foundation of other components of the compensation system. The unscientific salary system is the root of compensation for other diseases. The following two forms: first, in a long history of the company to become the main object of seniority pay, promotion and pay by personal service as the basis, leading to people and people with non-gang posts; Second, under the pressure of market competition as the main means to make up for the adjustment of overtime culture education of higher levels of fresh blood compensation, resulting in increased company contradictions, and eventually make the enterprise into a foreign competitive 
and not on the system unfair situation. At present, many SMEs in our country's salary system are imperfect, and some enterprises do not even have a salary system. Incomplete remuneration system, who will appear power, who is the final say?

\section{H. Tax awareness is too backward}

In real life, China's small and medium-sized enterprises rarely use this kind of management thought. For some high-end technical talents and contribute their labor to the enterprise, behoove should get higher pay, but in fact enterprises tend to form a single wage payment, after the enterprise to pay personal income tax, originally paid staff to pay to win is not very high[4]. If enterprises know how to use the concept of tax planning, equity incentives and other forms of pay remuneration, rather than in the form of wages paid, so that you can make the highend technical talents get more pay, so as to maximize the mobilization of their enthusiasm, can feel more comfortable service for enterprises. Most of the enterprises in our country still apply the consciousness of tax planning to the management of enterprise's salary.

\section{THE OPTIMIZATION STRATEGY ORIENTATION OF SALARY MANAGEMENT OF SMALL AND MEDIUM-SIZED ENTERPRISE IN OUR COUNTRY UNDER THE KNOWLEDGE ECONOMY}

The optimization of salary management of small and medium-sized enterprise in our country should be focused on the following aspects.

\section{A. Adapt to the enterprise development strategy}

Enterprises should consider many factors in developing guidance strategy. Such as the nature of the enterprise itself, the development direction of the future, the goals of the enterprise, different talent type and so on. The problems of salary management in the talent enterprise needs careful attention. For example, how to attract excellent talents, and excellent staff team in the enterprise can find a sense of belonging in the enterprise. And what kind of salary management mode to cultivate employees' sense of responsibility. In a word, make salary management supporting enterprise development strategy, to keep the staff to and stability.

\section{B. Strengthen internal salary effect}

Modern enterprise employees in the pursuit of higher income, but at the same time pay more attention to corporate culture, working environment, fair competition. The internal salary is gained by the psychological satisfaction, a sense of accomplishment and pride to work. The enterprise can through creating a favorable cultural atmosphere, to carry out the appropriate training and education, to give the staff promotion of equality of opportunity, focus on the needs of employees, pay attention to the communication with employees, etc. These measures to satisfy employees get psychological balance and encourage talents to innovation, and make recommendations for the development of enterprises [5].

\section{Sound the whole salary management system}

To establish and perfect the system of small and mediumsized enterprise salary management must adhere to three principles. Firstly, the principle of people-oriented, adhere to the people-oriented, from employee to employee, closely around employees. Secondly, fairness, only firmly grasp the "fairness", in the process of salary management system make will not be biased, but also in the process of implementation to be smooth. Thirdly, budget management, all compensation shall carry out the budget management, achieve the goal of saving the cost of compensation. In addition, a sound system of small and medium-sized enterprise salary management also must do the following. One is to further improve the content of the salary management system, especially should attach great importance to the salary allocation of often ignore concept, salary survey, the construction of performance management system. The second is to further standardize the format of the salary management system, the main responsibility and reduce the randomness of compensation management, improve the level of compensation management.

\section{Improving the welfare system}

The small and medium-sized enterprises must carry on the innovation in the welfare. On the basis of "five risks" of the employees, design of low cost, pluralism of welfare projects to utility maximization of welfare. For example, the senior technical personnel and senior management personnel, can use the vehicles of enterprise for free, reimbursement, whole journey with family members and additional commercial life insurance, etc. For junior staff, the enterprise can organize their collective outdoor travel regularly, and regular physical examination every year. The enterprise can send the flowers and the cake on staff birthday. Additionally, in holiday system, it should not only include the national legal holidays, also be according to the actual circumstance of enterprise and staff. The benefits of the length of service give corresponding these are able to retain staff welfare policy.

\section{E. Strengthen the performance assessment mechanism}

First of all, in the evaluation of performance assessment process, the enterprise must pay attention to the unity of the process and result. Enterprises in earnest examination staff, the working process of a series of should also be employees for the enterprise to bring the value of work results. Second, the results of evaluate as the content of the main basis of a salary distribution. According to the rules, salary allocation be rulesbased, it makes an objective and fair and reasonable performance evaluation results of the assessment. Finally, salary management for managers to use the performance review, Management process and results of the management personnel should be the implementation of rewards and punishment.

\section{$F$. Improve the quality of the staff}

Improve the comprehensive quality of small and mediumsized enterprise salary management can obtain from the following four aspects. One is the old staff led the new employees, seniority salary management personnel should help and support the new staff of salary management, and experience sharing with them, improve the level of enterprise salary management together. Second is self-improvement. Self-study is very important to actively enrich their own salary management knowledge, and improve the comprehensive quality. Third is to provide training opportunities, thus enhanced the degree of salary management of staff, and improve the level of the enterprise salary management [6]. Four is external introduction, good salary management in addition to the internal 
training can also be external introduction, small and mediumsized enterprises can from the outside the introduction of highly educated, high title personnel into the management team, to improve the whole quality of compensation management.

\section{G. Develop diversified incentives}

Single mode of compensation incentive is one of the main problems in the compensation system of SMEs in China. In order to solve this problem, we can use the stock option system of developed countries for reference. The application of the stock option system can effectively solve many essential problems in the operation of the company system. In the developed countries, under the existing stock option incentive, employees need to pay a cash when they exercise stock options, but because most of our employees are not rich, it is difficult to pay the cash. Therefore, it is appropriate for the employees to buy virtual shares instead of real stock options. For our small and medium-sized enterprises, we can not copy the incentive system of stock option compensation in developed countries, but should combine the actual situation of our country and actively and steadily implement various forms of enterprise employee stock ownership.

\section{H. Establish a tax planning awareness}

Tax planning is popular in terms of abiding by the national laws and regulations under the reasonable tax avoidance, which not only reduce the cost of enterprise, improve the working enthusiasm of the staff, and to expand domestic demand and promote economic development. On the premise of not violating the national tax policy, it is a relatively economic management measure to make full use of preferential tax policy and reasonable tax avoidance to lighten the tax burden for the staff and workers. Enterprises can make use of the performance pay policy, the year-end bonus payment time and the payment proportion adjustment, the salary welfare, the service income and the salary income reasonable transformation and so on. Of course, these enterprises in the selection of tax planning methods, all prior consent, once and the tax planning method can not only reduce the tax cost, improve employee satisfaction, but also can enhance the corporate image.

\section{CONCLUSION}

The small and medium-sized enterprises are an important force for economic development in our country. The salary management problems will seriously affect the enterprise talent problem, which affects the healthy development of the enterprise. Main salary strategy problems on salary, compensation system imperfect and unfair distribution, thus can't motivate employees, etc. On countermeasures, therefore, the small and medium-sized enterprises should make a compensation strategy suitable for their own development, perfect the compensation system. It should pay attention to the salary allocation fairness problem. It cannot copy other salary pattern of the enterprise, and should keep up with the pace of The Times, learn to choose advance salary management concept.

\section{REFERENCES}

[1] Levin, Henry, Firiancing Universities in Developing Countries.J. Forword The Famler Press, vol. 32, pp.118-121, 2016

[2] S.L. Liu, Analysis of spillover effects of human capital.J. Economic Science, vol.19, pp.79-85, 2016

[3] M. Li, Study on the cost-sharing of education of family preschool in China.J. Journal of Educational Science of Hunan Normal University, vol. 9, pp.216-321, 2016.

[4] Z.H. Yang, Area of higher education in our country is different from the other.J. Journal of Higher Education, vol. 12, pp.45-49, 2015

[5] C.S. Yang, Research on the impact of human capital investment on the income gap of urban residents is based on education and health perspectives.D. Beijing: Beijing Jiaotong University, vol.44, pp.92-105, 2016.

[6] X.P. Jiang, X.H. Hou, The higher education equity research in social transition period.J. Theoretical Perspective, vol.8, pp.136-141, 2015. 